\title{
Retina-Derived POU-Domain Factor-1: A Complex POU-Domain Gene Implicated in the Development of Retinal Ganglion and Amacrine Cells
}

\author{
Hao Zhou, ${ }^{1}$ Takashi Yoshioka, ${ }^{2}$ and Jeremy Nathans ${ }^{1,3}$ \\ ${ }^{1}$ Department of Molecular Biology and Genetics, 2Zanvyl Krieger Mind/Brain Institute, and ${ }^{3}$ Departments of Neuroscience \\ and Ophthalmology, and Howard Hughes Medical Institute, Johns Hopkins University School of Medicine, \\ Baltimore, Maryland 21205
}

\begin{abstract}
A novel POU-domain protein, retina-derived POU-domain factor-1 (RPF-1), has been identified through the isolation of cDNA and genomic DNA clones. In the adult, RPF-1 is expressed only within the CNS, where its expression is restricted to the medial habenulla, to a dispersed population of neurons in the dorsal hypothalamus, and to subsets of ganglion and amacrine cells in the retina. The human RPF- 1 gene spans $>125$ $\mathrm{kb}$ and gives rise to multiple differentially spliced transcripts. In the human retina, the most abundant mRNA isoforms are derived from an alternate splicing event that inserts an evolutionarily conserved peptide of 36 amino acids into the DNA recog-
\end{abstract}

nition helix of the POU-specific domain. In vitro, the RPF-1 POU domain lacking the insert binds to a consensus Oct-1 binding site, whereas the alternately spliced POU domain does not. RPF-1 protein first appears in the developing mouse retina at e11, where it localizes to neuroblasts that have recently migrated from the mitotic zone to the future ganglion cell layer. These data suggest that RPF-1 is likely to be involved in early steps in the differentiation of amacrine and ganglion cells.

Key words: retina; retinal ganglion cells; amacrine cells; POU domain; RPF-1; transcription factor
The retina is an attractive region of the central nervous system in which to study questions of neuronal differentiation. The vertebrate retina contains five major neuronal types: photoreceptor, bipolar, horizontal, amacrine, and ganglion cells. These are arranged in three layers, with photoreceptors in the outer layer; horizontal, bipolar, and amacrine cells in the central layer; and ganglion cells and displaced amacrine cells in the innermost layer (Rodieck, 1973; Dowling, 1987). Information flows from the site of light absorption in the outer retina through a series of processing steps in the central and inner retina, ultimately to the ganglion cells from which the axons of the optic nerve arise. Fach of the five major neuronal types listed above is divided further into subtypes. Classically, these neuronal subtypes have been characterized electrophysiologically, morphologically, and in the case of ganglion cells, by mapping the pattern of central projections. Although these approaches to classification were developed independently, they have become increasingly unified in recent years (Rodieck and Brening, 1983; Stone, 1983; Wassle and Boycott, 1991).

Elucidating the molecular basis of neuronal diversity is one of the central challenges in understanding retinal organization. The approach described here involves the identification of novel transcriptional regulatory molecules, with the idea that neuronal di-

Received Nov. 1, 1995; revised Dec. 28, 1995; accepted Jan. 4, 1996.

This work was supported by The National Eye Institute (National Institutes of Health) and the The Howard Hughes Medical Institute. We thank Dr. Clark Riley, Ms. Carol Davenport, Ms. Janine Ptak, and Ms. Lisa Eiben for synthesizing oligonucleotides; Dr. Keith Fry for the gift of AB.5 monoclonal antibody; Dr. Thomas li for assistance with computer analysis of the Oct-1 crystal structure; Dr. Stewart Hendry for advice on backfilling ganglion cells; and Drs. Mark Mollivar and Elizabeth O'Hearn for providing macaque eyes. We are grateful to Ms. Jennifer Macke and Drs. Patrick Tong and Stewart Hendry for helpful comments on this manuscript.

Correspondence should be addressed to Jeremy Nathans, 805 Preclinical Teaching Building, 725 North Wolfe Street, Johns Hopkins Medical School, Baltimore, MD 21205.

Copyright 1996 Society for Neuroscience $0270-6474 / 96 / 162261-14 \$ 05.00 / 0$ versity reflects, at least in part, differences in genetic regulatory events. A number of transcription factors have been identified previously in the retina, including the homeodomain proteins Pax6 (Walther and Gruss, 1991), Chx10 (Liu et al., 1994), SOHo-1 (Deitcher et al., 1994), and Isl-1 (Thor et al., 1991). Each of these proteins is also found outside the retina. One basic region/leucine zipper gene, NRL, is expressed only in the retina, but probably plays a limited role in distinguishing cell types because it is expressed in all retinal cell layers (Swaroop et al., 1992). The three members of the Brn-3 family of POU-domain genes may be important in generating retinal ganglion cell diversity on the basis of their expression in subsets of ganglion cells and their absence from other retinal cells (Gerrero et al., 1993; Xiang et al., 1993, 1995; Turner et al., 1994). The Brn-3 factors are also expressed in subsets of neurons in the dorsal root and trigeminal ganglia and in a small number of midbrain nuclei.

Given the large number of distinct neuronal types within the retina and the diversity of their physiological and morphological properties, it is reasonable to suppose that their development is controlled and coordinated by many as yet undiscovered transcriptional regulators. To identify such factors, we have focused on the POU-domain family. This family is defined by the presence of a bipartite DNA binding domain consisting of a POU-specific domain of $\sim 70$ amino acids and a POU homeodomain of $\sim 60$ amino acids, separated by a variable linker (Herr et al., 1988; Rosenfeld, 1991). Several members of this family show highly restricted patterns of expression and are known to control cell type-specific differentiation pathways [e.g., Pit-1 in the growth hormone-secreting cells of the anterior pituitary (Bodner et al., 1988; Ingraham et al., 1988; Li et al., 1991); Oct-2 in B-cells (Clerc et al., 1988; Scheidereit et al., 1988; Corcoran et al., 1993); and Unc-86 in various sensory neurons in the nematode Caenorhabditis elegans (Chalfie et al., 1981; Finney et al., 1988)]. In this 
paper we report the identification of a novel POU-domain factor, retina-derived POU-domain factor-1 (RPF-1), which is expressed in subsets of retinal ganglion and amacrine cells. Because RPF-1 first appears at the time when the inner retina begins to form and is highly restricted in its pattern of expression, it is likely to play a role in the determination and/or differentiation of these neuronal types.

\section{MATERIALS AND METHODS}

Genomic and cDNA clones. Whole genome Southern blots were performed as described in Sambrook et al. (1989), using GeneScreen Plus membranes (DuPont, Wilmington, DE). The emb/Brn-5 POU domain was identified in the course of sequencing a collection of POU-domain segments generated by degenerate PCR (He et al., 1989), using human visual cortex cDNA as template. Human RPF-1 genomic clones in bacteriophage $\lambda$ were obtained by screening of Sau3A partial digest libraries constructed in $\lambda$ EMBL3 (Frischauf et al., 1983), using both human genomic DNA and DNA from a strain of Saccharomyces cerevisiae carrying the human RPF-1 gene as a yeast artificial chromosome. For the latter libraries, two RPF-1 yeast artificial chromosomes were identified by PCR screening of pooled yeast DNAs with RPF-1 coding region primers (Research Genetics, Huntsville, AL). RPF-1 cDNA clones were obtained by screening of an adult human retina cDNA library constructed in $\lambda$ gt 10 (Nathans et al., 1986). Assembly of the entire RPF-1 genomic and cDNA sequence required several rounds of screening of both genomic and cDNA libraries, using progressively more $5^{\prime}$ proximal probes. Sequences at the extreme $5^{\prime}$ end of the coding region were obtained by rapid amplification of cDNA ends (RACE) (Frohman et al., 1988), using nested antisense primers for reverse transcription and PCR derived from sequences within the second and third exons. The RACE-PCR products were cloned into $\lambda$ gt10 using EcoRI sites within the PCR primers, and the resulting library was screened with an oligonucleotide probe derived from exon 2. Inserts from 160 hybridizing clones were amplified by PCR from single phage plaques and subjected to automated sequencing, using an antisense primer within exon 2.

Ribonuclease protection assay. Total RNA was isolated from mouse brain, eye, liver, kidney, lung, heart, spleen, and skeletal muscle by extraction with guanidinium thiocyanate followed by centrifugation through a $\mathrm{CsCl}$ shelf (Sambrook et al., 1989). Fifty milligrams of RNA from each tissue were hybridized with an in vitro-transcribed probe radiolabeled with $\left[{ }^{32} \mathrm{P}\right.$ ] uridine triphosphate in $80 \%$ formamide/ $/ 00 \mathrm{mM}$ sodium citrate $/ 300 \mathrm{~mm}$ sodium acetate at $45^{\circ} \mathrm{C}$ overnight. Samples were digested with a mixture of RNase $\mathrm{A}$ and RNase T1 and resolved on a denaturing polyacrylamide gel.

Generation and purification of antibodies. A DNA fragment encoding RPF-1 amino acids 356-441 was cloned in frame at the $3^{\prime}$ end of the bacteriophage $\mathrm{T} 7$ gene 10 coding region in the pGEMEX expression vector (Promega, Madison, WI) (Studier et al., 1990). The resulting fusion protein was produced in Escherichia coli, purified to near homogeneity by preparative SDS-PAGE, and used to immunize rabbits. For affinity purification of the antibodies, a DNA fragment encoding amino acids 387-441 was cloned in frame at the $3^{\prime}$ end of the maltose binding protein (MBP) coding region in the pMAl-cR1 expression vector (New England Biolabs, Beverly, MA). The resulting fusion protein was produced in $E$. coli and purified to apparent homogeneity on an amylose affinity resin. The antibody was affinity-purified using $1 \mathrm{mg}$ of the MBP fusion protein coupled to an AminoLink column (Pierce, Rockford, IL), with elution in $0.1 \mathrm{M}$ glycine, $\mathrm{pH} 2.9$.

Immunocytochemistry. To prepare mouse and monkey retina cryosections, eyes were fixed in PBS with $4 \%$ paraformaldehyde at $4^{\circ} \mathrm{C}$ for $2 \mathrm{hr}$ after which the cornea, lens, and vitreous were removed. The eye cups were fixed further in $4 \%$ paraformaldehyde overnight at $4{ }^{\circ} \mathrm{C}$ and cryoprotected by overnight incubation with $30 \%$ sucrose in PBS. Mouse eye cups were embedded in OCT compound (Miles, Elkhart, IN) and frozen in liquid $\mathrm{N}_{2}$; monkey eye cups were opened, and pieces of retina were isolated before embedding. Ten micrometer sections were cut on a cryostat at $-20^{\circ} \mathrm{C}$ and mounted on gelatin-coated slides. To prepare cryosections of mouse brain, adult animals were anesthetized and perfused through the left ventricle with PBS followed by $4 \%$ paraformaldehyde in PBS. Whole brains were removed and postfixed in $4 \%$ paraformaldehyde in PBS at $4^{\circ} \mathrm{C}$ overnight, cryoprotected in $30 \%$ sucrose, embedded in OCT compound, and frozen in liquid $\mathrm{N}_{2}$. Serial $25 \mu \mathrm{m}$ coronal sections were collected on slides, postfixed in $100 \%$ methanol for
3 min, and immunostained with affinity-purified anti-RPF-1 antibodies, using the Vectastain ABC system with the VIP (purple) substrate (Vector Laboratories, Burlingame, CA). For the analysis of RPF-1 expression during mouse development, mice were mated overnight and examined the next morning. The presence of a vaginal plug was taken as evidence of fertilization, and one half day of gestation was considered to have elapsed. Embryos at various stages of development were removed from the uterus, immersed in $4 \%$ paraformaldehyde in PBS overnight, and processed as described above for brain sections. Neuroanatomic assignments in the developing and adult mouse brain were made with reference to Paxinos and Watson (1986), Sidman et al. (1971), and Schambra et al. (1992).

For immunocytochemistry on wholemount retinas, the eye cup was fixed and cryoprotected in $30 \%$ sucrose, as described above. The retina was then gently dissected away from the choroid and sclera and frozen and thawed 8-10 times in 2-methyl butane to aid the penetration of the antibodies. The retina was preincubated with $5 \%$ normal goat serum in PBS for $8-16 \mathrm{hr}$ at $4^{\circ} \mathrm{C}$ and then incubated with primary antibody in PBS for $10 \mathrm{~d}$ at $4^{\circ} \mathrm{C}$. The retina was washed in PBS three times, $4 \mathrm{hr}$ each at $23^{\circ} \mathrm{C}$, incubated with biotinylated secondary antibody and/or fluorescein isothiocyanate-conjugated secondary antibody for $2 \mathrm{~d}$ at $4^{\circ} \mathrm{C}$, washed again in PBS three times, $4 \mathrm{hr}$ each at $23^{\circ} \mathrm{C}$, and incubated with avidinbiotin complex (Vector Laboratories) for $2 \mathrm{~d}$. The retina was given a final wash in PBS three times, $4 \mathrm{hr}$ each at $23^{\circ} \mathrm{C}$, and then stained with the VIP (Vector Laboratories) substrate kit. The staining reaction was terminated by washing in PBS for 5-10 $\mathrm{min}$, and the retina was flatmounted onto a slide with Aquamount (Polyscience, Niles, IL).

Retrograde labeling from the lateral geniculate nucleus (LGN). Two monkeys were injected with Texas red-conjugated or fluoresceinconjugated dcxtrans (10,000 MW) (Molecular Probes, Eugene, OR). The monkeys were anesthetized with ketamine $(20 \mathrm{mg} / \mathrm{kg}, \mathrm{i} . \mathrm{m}$.) and nembutal (15 mg/kg/hr, i.v.) and mounted in a stereulaxic frame. Sterile surgical procedures were used to make a small craniotomy over the central sulcus, and stereotaxically aimed tungsten microelectrodes were lowered through the cortex into the dorsal thalamus. Multi-unit activity was mapped during presentation of visual stimuli, which permitted the borders of the dorsal LGN to be mapped with penetrations spaced $1 \mathrm{~mm}$ apart. The mapping electrode was withdrawn, and a multibarrel glass pipette, pulled and filled with $5 \%$ Texas red-dextran or $5 \%$ fluorescein dextran in sterile saline, was inserted at previously identified sites in the LGN. After visually evoked responses were identified again, the dextran solution was ejected iontophoretically ( $5 \mu \mathrm{A}$, with a $7 \mathrm{sec}$ on/off duty cycle) during a period of 20-25 min. In onc cxpcriment, injections were made at each of several sites in both parvocellular and magnocellular layers, and, in a second experiment, at a single site in layer 6 . After all injections were completed, the craniotomy was filled with dental cement, and the wound was closed with sutures. Two or 3 weeks later, the monkeys were anesthetized with ketamine and injected with a lethal dose of nembutal $(100$ $\mathrm{mg} / \mathrm{kg}$, i.v.). They were then perfused through the heart with 4 liters of $4 \%$ paraformaldehyde in $0.1 \mathrm{M}$ phosphate buffer, $\mathrm{pH} 7.4$. The brain and eyes were removed and postfixed in perfusate. Blocks of the LGN were then placed in $20 \%$ buffered sucrose at $4^{\circ} \mathrm{C}$ for several days. They were frozen and cut at $30 \mu \mathrm{m}$, collected serially, and mounted on clean slides. Injection sites were identified under a fluorescence microscope.

Microscopy and image analysis. Nomarsky and immunofluorescence images were obtained using a Zeiss Axiophot microscope and Kodak Eklachrome Elite slide film. Images were digitized at a final resolution of 300 pixels/inch, using an AGFA Vision 35 color scanner and Adobe PhotoShop and ClarisDraw software.

Recombinant POU domains and DNA binding. Plasmids encoding the POU domain of Oct-1 (amino acids 276-443), the consensus RPF-1 POU domain (amino acids 465-628), and the alternate RPF-1 POU domain (amino acids $465-628$ but including the 36 amino acid insert) fused to glutathione-S-transferase (GST) were constructed by PCR amplification of the corresponding cDNA sequences followed by cloning into the GST expression vector pGEX-2T (Pharmacia, Alameda, CA). All constructs described in this paper that were produced using PCR were sequenced to rule out PCR-induced mutations. Recombinant proteins were expressed in E. coli and purified by affinity chromatography on glutathione-agarose beads. For gel mobility shift experiments with a pure oligonucleotide target, kinased double-stranded DNA $(\sim 0.1 \mathrm{ng})$ was incubated with between 1 and $150 \mathrm{ng}$ of GST fusion protein in $15 \mu \mathrm{l}$ of binding buffer [ 10 mM HEPES, pH 7.5, $50 \mathrm{~mm} \mathrm{KCl,} 1$ mм EDTA, 0.1\% Triton X-100, 5\% glycerol, $0.1 \mathrm{~mm}$ dithiothreitol (DTT), $50 \mathrm{mg} / \mathrm{ml}$ poly(DI-DC), and $0.1 \mathrm{~mm}$ phenylmethylsulfonyl fluoride (PMSF)] for $20 \mathrm{~min}$ at room temperature, 
A
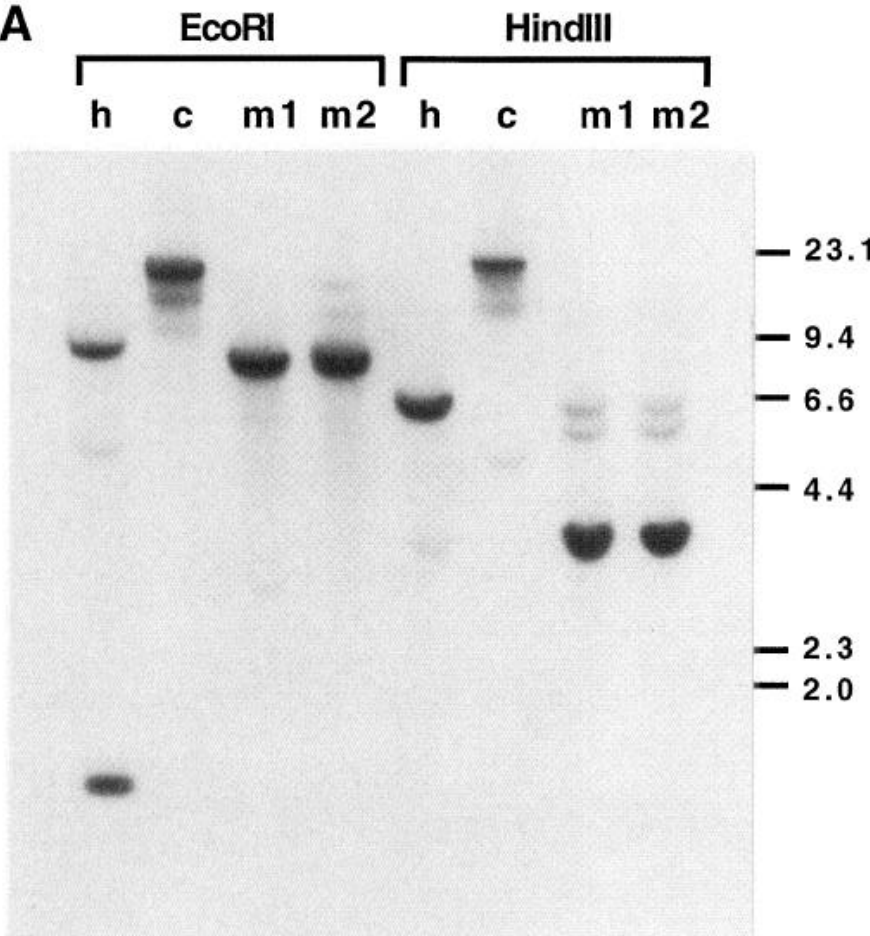

B

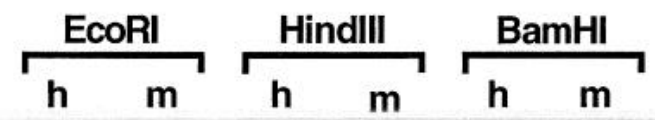

$-23.1$

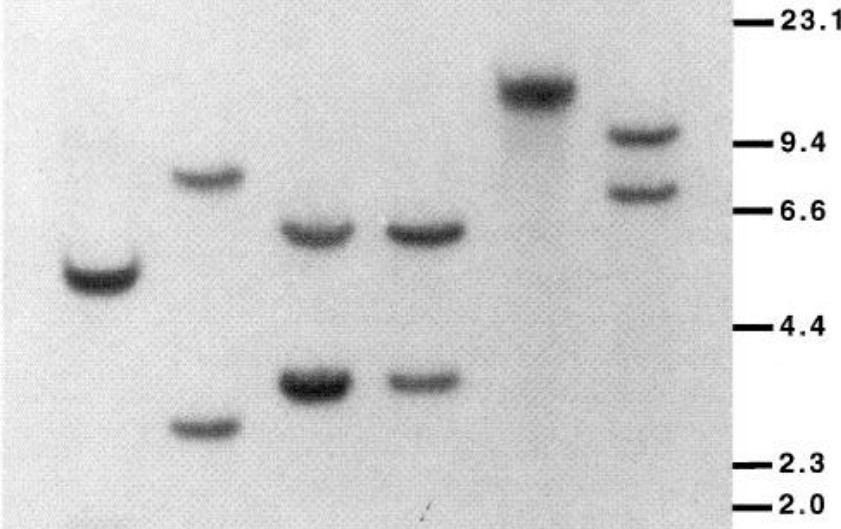

Figure 1. Whole genome Southern blots with POU-domain probes from emb/Brn-5 and RPF-1. Mouse and human DNA were digested with the indicated restriction enzymes and analyzed by whole genome Southern blotting with either an emb/Brn-5 POU-domain probe $(A)$ or an RPF-1 POU-domain probe $(B)$. Blots were hybridized in $5 \times \mathrm{SSC}, 50 \%$ formamide at $37^{\circ} \mathrm{C}$, and washed in $0.2 \times \mathrm{SSC}$ at either $55^{\circ} \mathrm{C}(A)$ or $50^{\circ} \mathrm{C}(B)$. Several bands in the EcoRI and Hind III digests that hybridize weakly with the emb/Brn5 POU-domain probe hybridize strongly with the RPF-1 POU-domain probe. Genomic DNA samples are $h$, human; $m$ and $m 1$, mouse (Balb/c); $m 2$, mouse (cell line BW); $c$, chicken. DNA size standards (in kilobases) are shown to the right.

and the resulting complexes were resolved on a $4 \%$ nondenaturing polyacrylamide gel $0.25 \times$ Tris borate EDTA (TBE) buffer. Binding site selections (Thiesen and Bach, 1990) were performed essentially as described in Xiang et al. (1995). In brief, for selection using the protein linked to glutathione beads, $100 \mathrm{ng}$ of the double-stranded oligonucleotide target was mixed with $40 \mathrm{ng}$ of GST fusion protein prebound to glutathione-agarose beads in $0.5 \mathrm{ml}$ binding buffer $[20 \mathrm{~mm}$ Tris- $\mathrm{HCl}, \mathrm{pH}$ $8.0,50 \mathrm{~mm} \mathrm{KCl}, 0.5 \mathrm{~mm}$ EDTA, $1 \mathrm{~mm}$ DTT, $10 \%$ glycerol, $20 \mu \mathrm{g} / \mathrm{ml}$ bovine serum albumin, and $2 \mu \mathrm{g} / \mathrm{ml}$ poly-D(I-C)]. After incubation for 1 $\mathrm{hr}$ at $4^{\circ} \mathrm{C}$ with gentle rotation, the beads were washed twice in $1 \mathrm{ml}$ of binding buffer without poly-D(I-C), resuspended in $30 \mu \mathrm{l}$ water, and boiled for $2 \mathrm{~min}$. Ten microliters of the eluted DNA was used as a template for 15 cycles of PCR, followed by one additional cycle containing a large excess of primer and Taq polymerase to ensure that the final products were double-stranded newly synthesized homoduplexes. After five rounds of enrichment and amplification, the PCR products were cloned into pBluescript, and individual clones were sequenced. For selection using preparative mobility shift gels, the radiolabeled target DNA was incubated with $50 \mathrm{ng}$ of the GST fusion protein at room temperature for $20 \mathrm{~min}$ in $10 \mathrm{~mm}$ HEPES, pH 7.5, $50 \mathrm{~mm} \mathrm{KCl}, 1 \mathrm{~mm}$ EDTA, $0.1 \mathrm{~mm}$ DTT, $0.1 \%$ Triton X-100, $5 \%$ glycerol, $50 \mu \mathrm{g} / \mathrm{ml}$ poly$\mathrm{D}(\mathrm{I}-\mathrm{C})$, and $0.1 \mathrm{~mm}$ PMSF. The complexes were resolved on a $4 \%$ native polyacrylamide gel in $0.25 \times \mathrm{TBE}$, localized by autoradiography, excised, eluted in $300 \mu \mathrm{l}$ of $0.5 \mathrm{M} \mathrm{NH}_{4} \mathrm{OAc}$ and $1 \mathrm{~mm}$ EDTA, and used as templates for the next round of PCR, as described above.

\section{RESULTS}

\section{Identification and characterization of RPF-1}

RPF-1 was identified initially by low-stringency hybridization to the POU domain of the human emb/Brn-5 gene (Anderson et al., 1993; Okamoto et al., 1993). In this experiment, weakly hybridizing bands not accounted for by the emb/Brn-5 gene were observed in Southern blots of human, mouse, and chicken genomic DNA (Fig. 1). Isolation and characterization of genomic clones contain- ing the weakly hybridizing human and mouse fragments revealed the presence of a novel class VI POU-domain gene, RPF-1. To characterize the complete RPF-1 coding region, cDNA clones were isolated from a human retina cDNA library. Although these cDNA clones were found at a frequency of $<1$ per $10^{5}$ recombinants, subsequent RNase protection and immunostaining experiments showed the retina to be the richest source of RPF-1 transcripts and protein. To characterize the intron/exon structure of the RPF-1 gene, clones encompassing each of the exons were isolated from bacteriophage $\lambda$ libraries prepared by using either human genomic DNA or DNA from two yeast strains that harbor overlapping human genomic segments as artificial chromosomes. A comparison of sequences from eight independent cDNA clones, 160 cloned 5' RACE-PCR products, and the exon and immediately adjacent intron regions of the cloned genomic segments shows that the RPF-1 gene is divided into at least 10 exons and is unusually large, encompassing $>125 \mathrm{~kb}$ (Fig. 2). Because the exact start sites of transcription have not been determined, the RPF-1 gene could have additional 5' noncoding exons.

The cDNA and RACE-PCR sequence analysis reveals four positions at which alternate splicing generates distinct protein isoforms (Figs. 2, 3). In each case the sequence of the corresponding genomic DNA reveals a consensus splice junction at the predicted intron/exon boundary. The first alternative splice is found at the $5^{\prime}$ end of the transcript, where one of four distinct first exons are spliced onto a unique second exon. The four alternate first exons would be predicted to generate three distinct amino-terminal sequences, if in each case the most 5' proximal in-frame ATG were used as the initiator methionine codon. The 


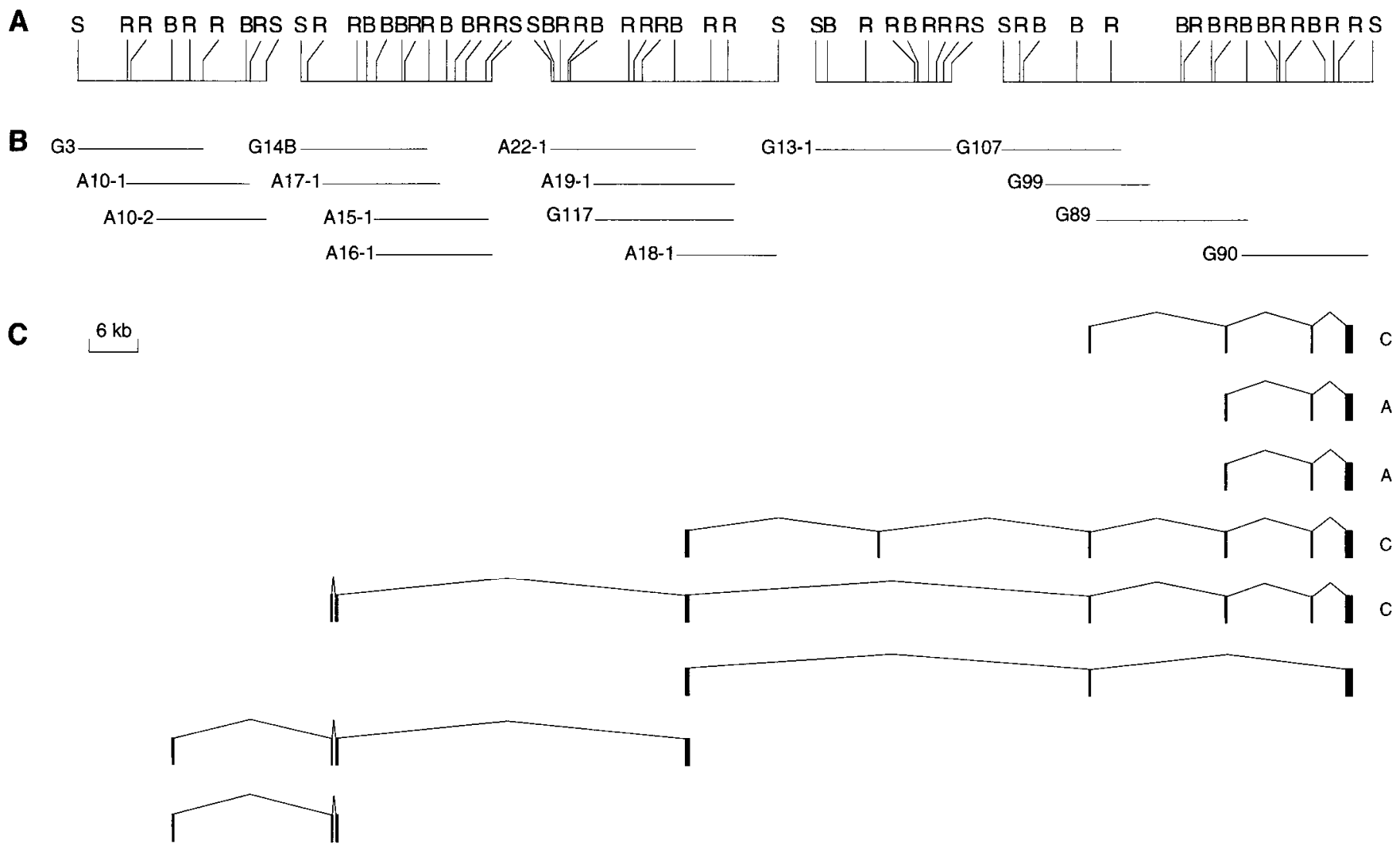

Figure 2. Human RPF-1 genomic and cDNA clones. $A$, Restriction map of human genomic DNA. $B, \lambda$ genomic clones used to derive the genomic map. Several gaps in the map are indicated. The orientation of the second and fourth genomic phage groups with respect to the direction of transcription is unknown. $C, \mathrm{cDNA}$ clones isolated from the human retina contain either the consensus or the alternate POU-domain exon structure, as indicated to the right by $A$ or $C$, respectively. The cDNA clones define exons 2-10; the four alternate versions of exon 1, defined by RACE-PCR, are not shown and have not yet been mapped to genomic DNA. $B, B a m \mathrm{HI} ; R, E c o$ RI; $S$, SalI.

second alternative splice results in the variable skipping of exon 6 , which produces an in-frame insertion/deletion of 47 amino acids in a region of the protein upstream of the POU domain. The third alternative splice skips both exons 8 and 9 , splicing exon 7 and to the $3^{\prime}$ proximal splice acceptor in exon 10 (see below). The resulting open-reading frame is frameshifted at the exon 7-exon 10 splice junction, producing a truncated protein that lacks all POU-domain sequences.

The fourth alternative splice occurs within the POU-specific domain in exon 10. The amino-terminal half of the POU-specific domain is encoded within exon 9 and is spliced to one of two alternate acceptor sites in exon 10. As shown in Figure $3 A, C$, transcripts generated by splicing to the $3^{\prime}$ proximal acceptor code for a POU domain that conforms well to the consensus POUdomain sequence (referred to hereafter as the "consensus" POU domain). As shown in Figure $3 B$, however, use of the $5^{\prime}$ proximal splice acceptor in exon 10 generates a transcript that codes for a POU-specific domain with an in-frame insertion of 36 amino acids (referred to hereafter as the "alternate" POU domain). A comparison of the RPF-1 sequence and the Oct-1-DNA cocrystal structure shows that the inscrtion is in the center of the DNA recognition helix of the POU-specific domain (Figs. 3C, 4C) (Klemm et al., 1994). The 36 inserted amino acids have no apparent homology to other POU-domain sequences or to any sequences in the current GenBank database. That this alternate splicing event is of functional significance is suggested by its evolutionary conservation. A comparison of mouse and human
RPF-1 exon 10 sequences reveals in both species the presence of the two splice-acceptor sequences and complete identity of the alternate exon at the nucleotide level (Fig. 3B). Although some part of this sequence conservation may reflect constraints related to the control of differential splicing, completc identity at the amino acid level suggests that this polypeptide segment has a definite three-dimensional structure and biological function.

A comparison of the complete human RPF-1 sequence and the sequences of other POU-domain factors indicates that RPF-1 represents a novel POU-domain gene. The closest homologs currently known are emb/Brn-5 (isolated from mouse and rat, respectively) (Anderson et al., 1993; Okamoto et al., 1993) and POU[C] (isolated from zebrafish) (Johansen et al., 1993). This comparison suggests further that $\mathrm{emb} / \mathrm{Brn}-5$ and $\mathrm{POU}[\mathrm{C}]$ are orthologs, consistent with the similar and widespread pattern of expression of each of these genes in the developing CNS.

\section{Alternate and consensus POU domains}

To investigate the biological significance of the 36 amino acid insertion within the POU-specific domain, we first asked whether transcripts encoding this alternate form constituted rare variants or whether they represented an appreciable fraction of RPF-1 transcripts. Reverse transcriptase (RT)-PCR analysis of human retina first-strand cDNA was performed by using one primer within exon 9 and a second primer within exon 10 that lies downstream of the two splice-acceptor sites (Fig. 4A,B). Two distinct PCR products were obtained, and these conformed in size 


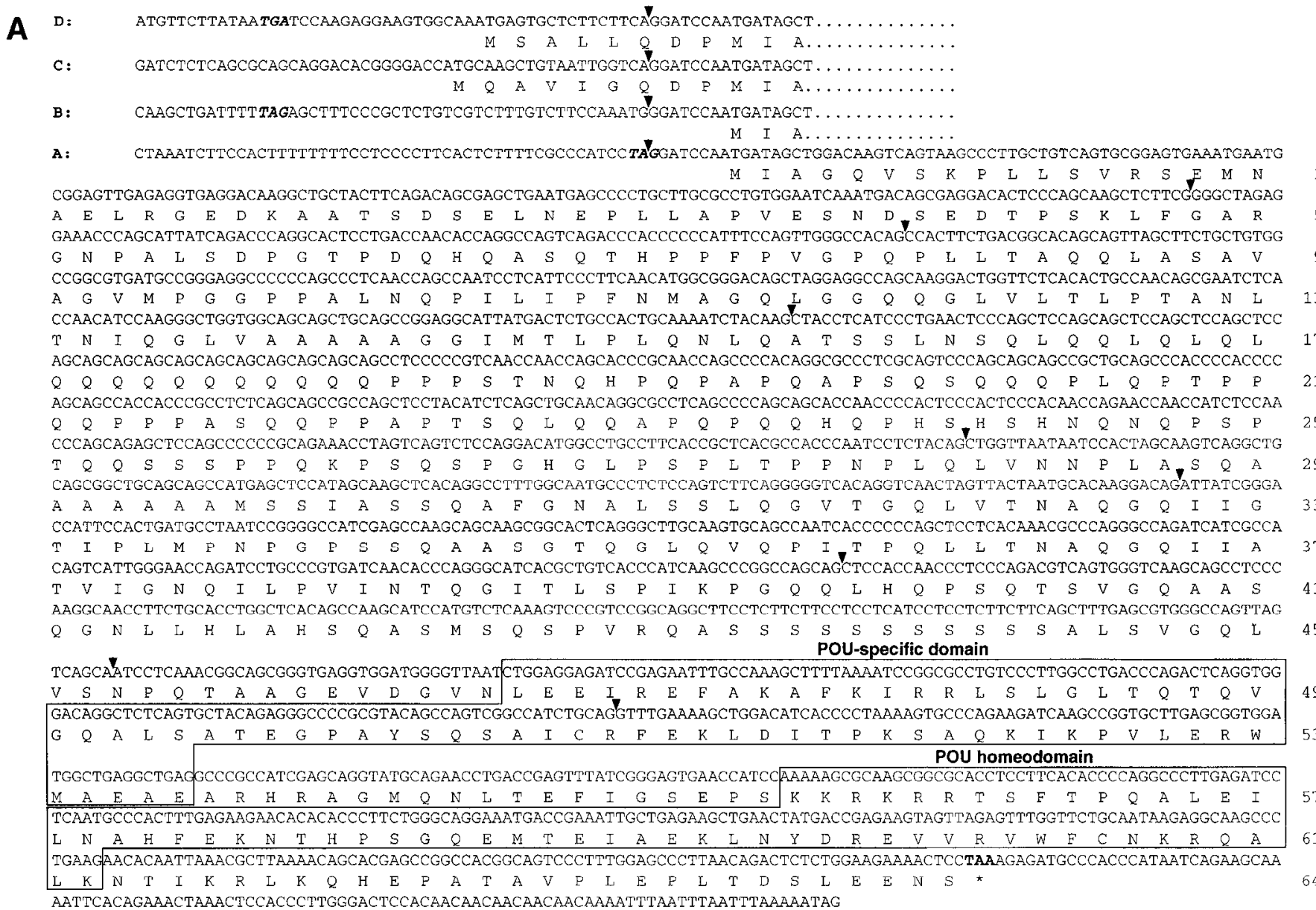

B ATTTTCCCCCCCAGACACACCATCCTGAGAAGCCACTTTTTCCTACCACAGGAAGCCCAAGAGAACACTATAGCTAGCAGTCTGACAGCCAAACTGAACCCTGGCCTTTT AATTCTCCCCCCAGACACACCATCCTGAGAAGCCACTTTTTCCTACCACAGGAAGCCCAAGAGAACACTATAGCTAGCAGTCTGACAGCCAAACTGAACCCTGGCCTTTT

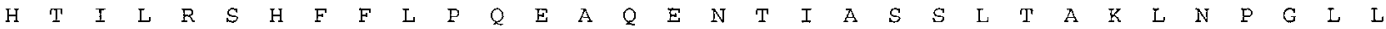
$\begin{array}{llllllllllllllllllllllllllllllll}H & \mathrm{I} & \mathrm{I} & \mathrm{L} & \mathrm{R} & \mathrm{S} & \mathrm{H} & \mathrm{F} & \mathrm{F} & \mathrm{L} & \mathrm{P} & \mathrm{Q} & \mathrm{E} & \mathrm{A} & \mathrm{Q} & \mathrm{E} & \mathrm{N} & \mathrm{T} & \mathrm{I} & \mathrm{A} & \mathrm{S} & \mathrm{S} & \mathrm{L} & \mathrm{T} & \mathrm{A} & \mathrm{K} & \mathrm{L} & \mathrm{N} & \mathrm{P} & \mathrm{G} & \mathrm{L} & \mathrm{L}\end{array}$
emb/Brn-5

POU [C]

Pit-1.

oct-1

unc 86

RPF - 1

emb/Brn-5

$\mathrm{POU}[\mathrm{C}]$

Pit-1

OCL-1

unc 86

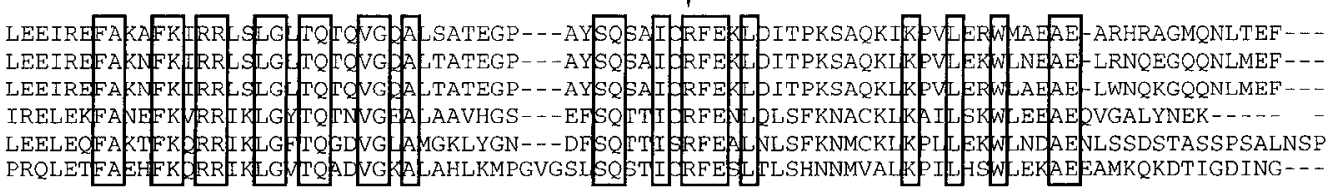

Figure 3. RPF-1 nucleotide and amino acid sequences. $A$, The sequence of human RPF-1. The figure shows the consensus POU-domain exon structure with all of the internal exons present. Intron locations are indicated by vertical arrowheads. Four alternative first exon sequences (labeled $A-D$ ) are shown; among 84 cloncd RACE-PCR products that included a first cxon, they were found in the ratio 73:5:4:2 (for A/B/C/D). The single cDNA clone that contains a first exon is of class D. Class A, the most common class of first exon found by RACE, is shown as a contiguous sequence with the rest of the coding region; the less common classes B-D are indicated at the top of the figure. Deduced amino acid sequences are shown on the assumption that for each mRNA the most $5^{\prime}$ ATG is used for translation initiation. Three of the four alternate first exons have an in-frame stop codon $5^{\prime}$ of the putative initiator ATG. B, Alternate splice acceptor sites in exon 10 generate the alternate or consensus POU-specific domain in human (top) and mouse (bottom) RPF-1 genes. $C$, Alignment of POU-domain sequences for the three known class VI POU-domain proteins, the consensus RPF-1 POU domain, emb/Brn-5 (Anderson et al,, 1993; Okamoto et al., 1993), and pou(c) (Johansen et al., 1993), with Pit-1, Oct-1, and Unc-86 (Herr et al., 1988). The point of insertion of the 36 amino acids in the alternate RPF-1 POU-specific domain is shown by a vertical arrow. 
A

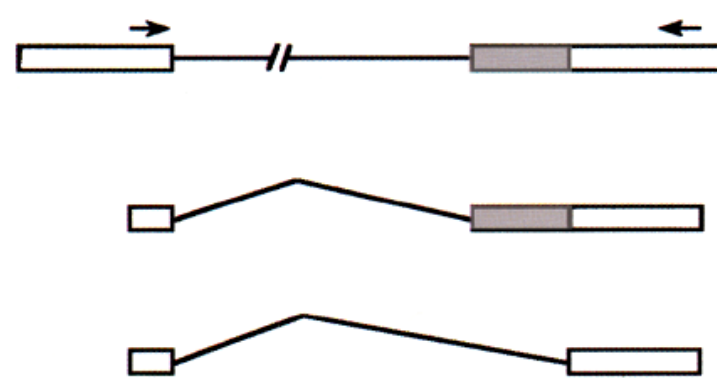

B

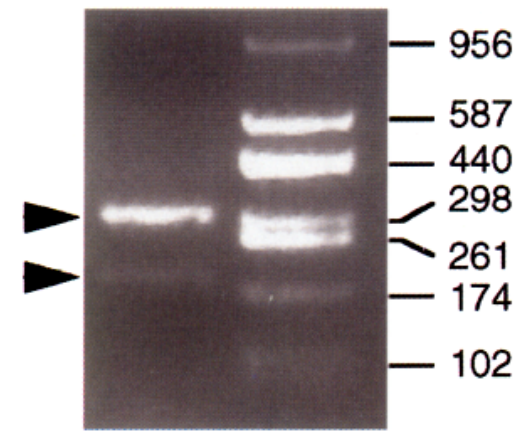

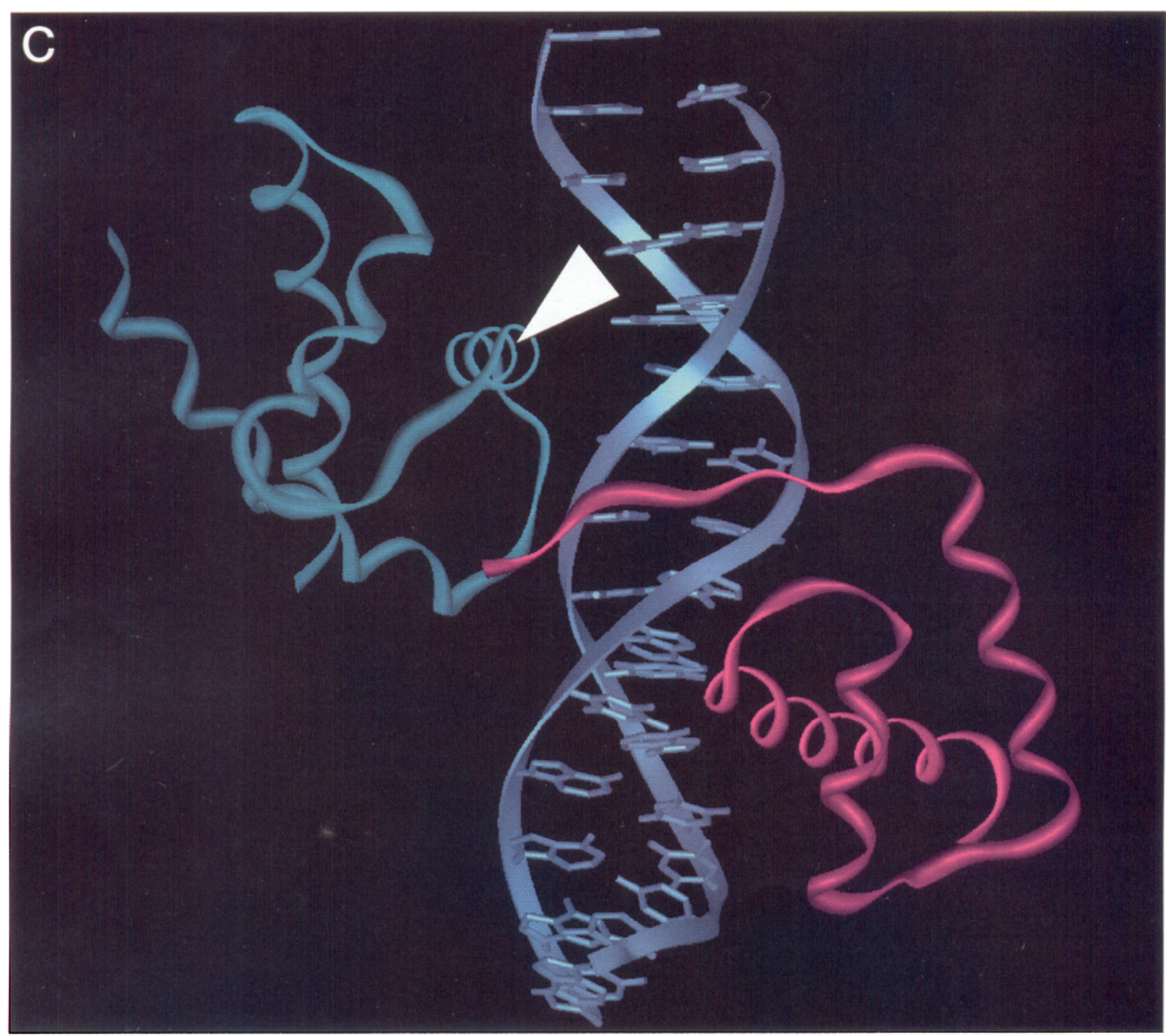

Figure 4. Alternately spliced RPF-1 POU domains are present in human retina RNA. A, Top, Strategy for RT-PCR with one primer from exon 9 (encoding the amino-terminal half of the POU-specific domain) and a second primer from exon 10 (encoding the C-terminal half of the POU-specific domain and the POU homeodomain). The structures of PCR products generated from mRNAs encoding the alternate and consensus POU domains are shown at the center and bottom, respectively. Sequences encoding the 36 amino acid insert in the alternate POU domain are represented by a black region. $B$, Agarose gel electrophoresis of products obtained from the RT-PCR reaction diagrammed in $A$, using human retina first-strand cDNA as a template, shows bands at 310 and $200 \mathrm{bp}$; subcloning and sequencing of these products show that they arise from the use of alternate splice acceptors within the POU-specific domain as shown in Figure $3 B$. The 310 bp PCR product, which corresponds to the alternate POU domain, is found reproducibly in higher yield than the $200 \mathrm{bp}$ product, which encodes the consensus POU domain. $C$, Predicted location within the POU-specific domain of the 36 amino acid insertion encoded by the alternate splice form of RPF-1. Fitting of the RPF-1 POU domain to the Oct-1 POU domain-DNA crystal structure (Klemm et al., 1994) shows that the insertion occurs in the middle of the recognition helix, as indicated by the arrowhead (see Fig. $3 C$ for the primary sequence alignment with Oct-1). The POU-specific domain is shown in blue and the POU homeodomain in red. 


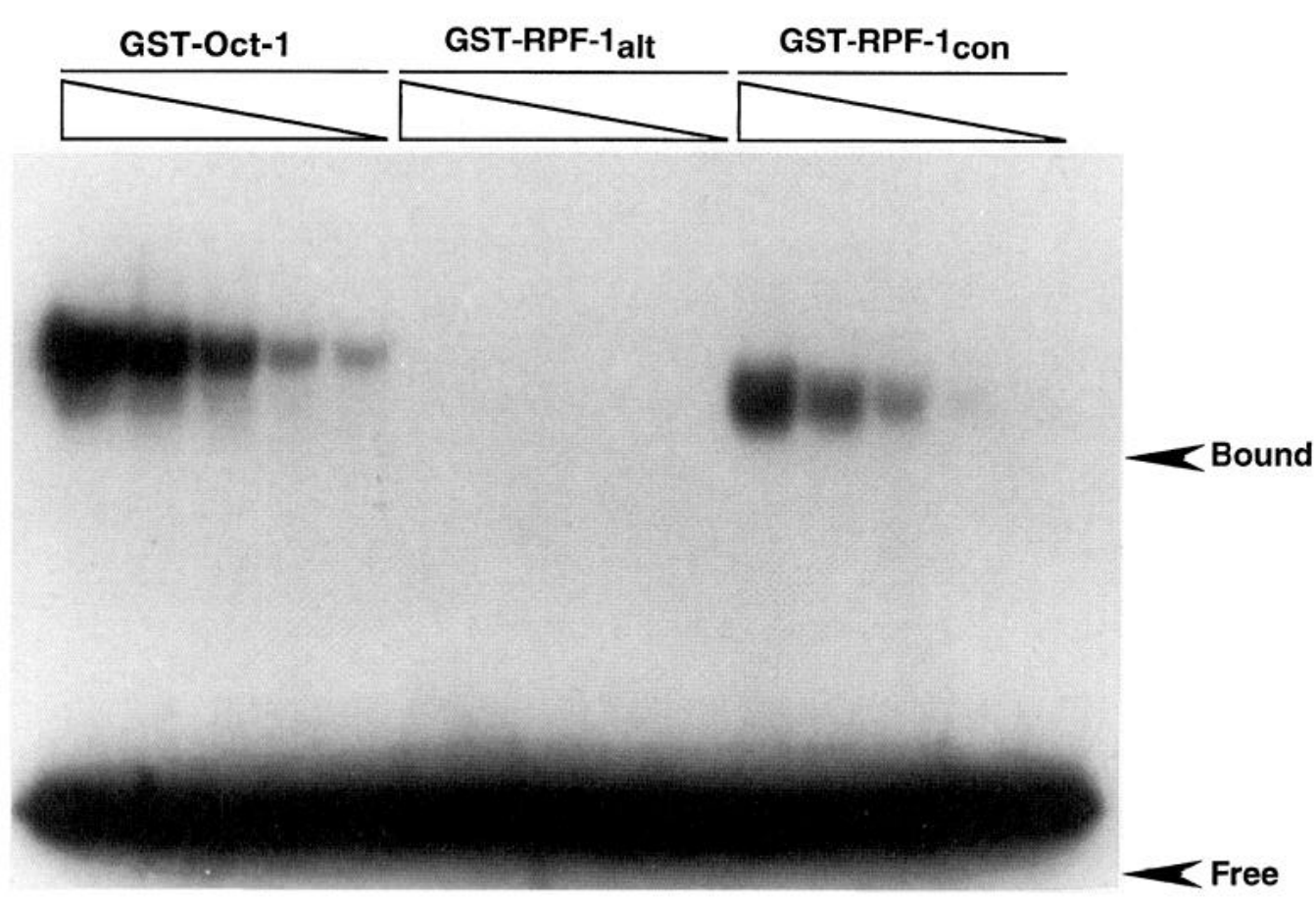

Figure 5. DNA binding properties of consensus and alternate RPF-1 POUdomain GST fusion proteins. Gel mobility shift analysis of purified POUdomain fusion proteins containing the Oct-1 POU domain (left), the alternate RPF-1 POU domain (center), and the consensus RPF-1 POU domain (right). In each case the radiolabeled doublestranded DNA probe contains the Oct-1 consensus binding site, ATGCAAAT. Within each set of lanes, the protein concentration decreases (from left to right) in twofold steps starting at 10 $\mu \mathrm{g} / \mathrm{ml}$. and sequence to the two predicted splicing events. Interestingly, the larger of the two PCR products was reproducibly obtained in higher yield. We note that the ratio of the larger to the smaller PCR product should represent a lower estimate of the ratio of the corresponding transcripts, as the smaller of the two PCR products would be expected to amplify with an efficiency equal to or greater than that of the larger product.

To examine the functional effects of the 36 amino acid insertion, we studied the DNA binding properties of GST fusion proteins containing either the consensus or alternate RPF-1 POU domains. In one series of experiments, the RPF-1 POU-domain fusion proteins were immobilized on glutathione beads and used to enrich for target DNA molecules from a pool of synthetic double-stranded DNA segments in which a central core of 16 bases had been randomized. After five rounds of enrichment, the consensus and the alternate RPF-1 POU-domain-GST fusions had selected sequences containing (A/T)AAT and TAAT, respectively, the consensus expected if protein-DNA binding was mediated by the POU homeodomain. A parallel experiment using a GST fusion protein carrying the Oct-1 POU domain efficiently selected the consensus Oct- 1 site ATGC(A/T)AAT. In a second series of experiments, preparative mobility shift gels were used as a more stringent enrichment method; in these experiments, the pool of synthetic double-stranded DNA segments had a central core of 24 randomized bases. Using this protocol, the consensus RPF-1 POU-domain-GST fusion again selected sequences containing (A/T)AAT, whereas the alternate RPF-1 POU-domainGST fusion failed to enrich for any subpopulation of sequences. These data indicate that the alternate POU-specific domain binds less tightly to its target(s). This difference in DNA binding affinity between the consensus and alternate splice forms of the RPF-1 POU domain is also apparent in comparing their binding to the Oct-1 consensus site ATGCAAAT (Fig. 5). At all protein concentrations tested, the alternate POU domain failed to bind, whereas the consensus form bound with an efficiency approximately one tenth that of the Oct-1 POU domain. Although these experiments have failed to demonstrate high-affinity DNA binding by the alternate RPF-1 POU domain and have demonstrated DNA binding by the consensus RPF-1 POU domain that is of lower affinity and specificity than that of the Oct-1 POU domain, the possibility exists that interactions with other parts of RPF-1 or with other proteins could stabilize DNA protein complexes that are not seen with the purified POU-domain fusion proteins.

\section{Developmental distribution of RPF-1 in the mouse}

The distributions of RPF-1 RNA and protein were determined in the adult mouse by RNase protection and by immunostaining with affinity-purified anti-RPF-1 antibodies. In the adult, RPF-1 transcripts are found only within the nervous system (Fig. 6). Immunostaining of mouse brain, retina, spinal cord, and dorsal root ganglia shows that RPF-1 is present only in the medial habenula, in scattered cells in the hypothalamus, and in the retina, where it is found in subsets of cells in the ganglion cell layer and at the inner edge of the inner nuclear layer (Fig. 7). As expected for a putative transcription factor, RPF-1 immunoreactivity is confined to nuclei. In the retina, a reproducible heterogeneity is seen in the intensity of immunostained cells. We note that the anti-RPF-1 antibodies do not cross-react with the most closely related POUdomain factor currently known, emb/Brn-5, because they do not stain cerebral cortex where emb/Brn-5 is most abundant (Anderson et al., 1993; Okamoto et al., 1993).

During development, RPF-1 is expressed most prominently in the retina. Staining is also seen in a small number of cells in the developing midbrain and in the spinal cord. In the mouse retina, the ganglion cell layer first forms in the central retina at approximately e11-e12, when the first postmitotic neurons migrate inward from the adjacent zone of proliferating neuroblasts. RPF-1 immunoreactivity is first observed at e11 in the future ganglion cell layer in the central retina, and as development proceeds, RPF-1-expressing cells accumulate in the inner retina (Fig. 8). 

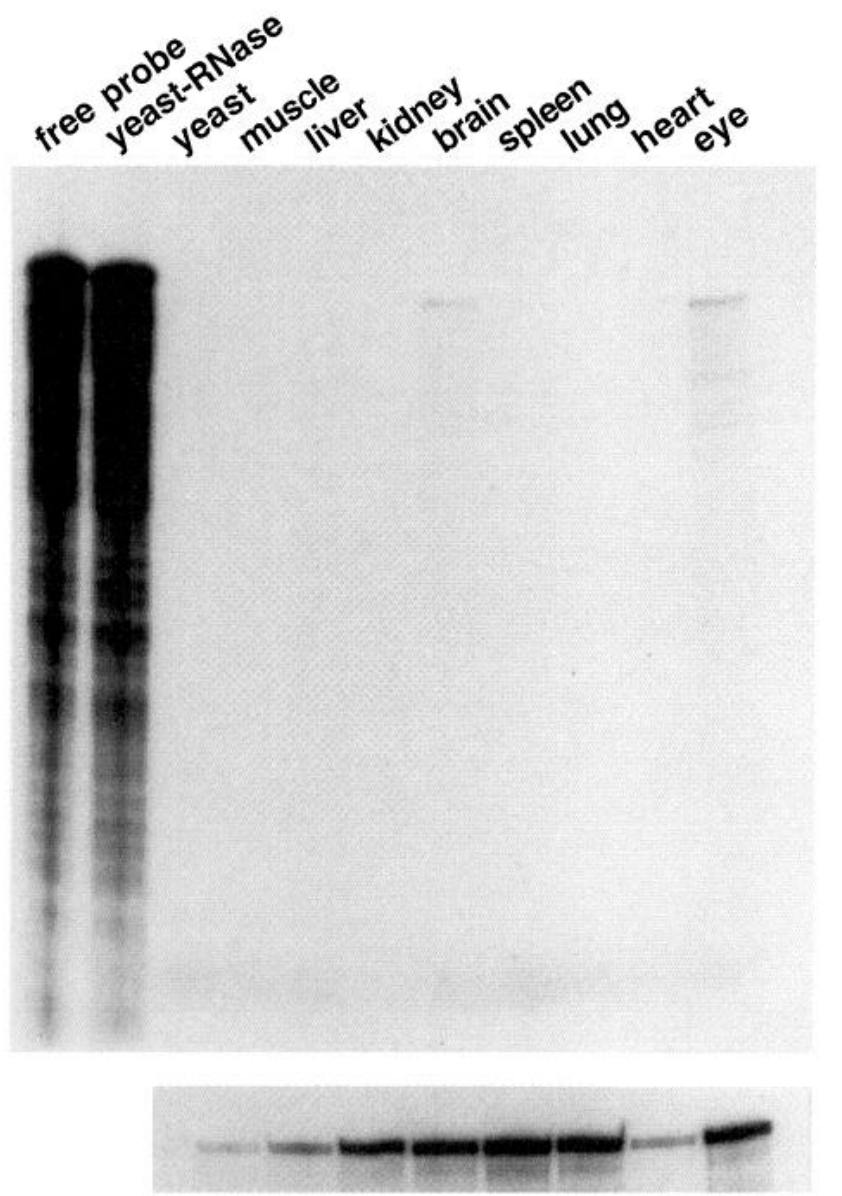

Figure 6. Tissue distribution of mouse RPF-1 transcripts. The top shows RNase-protected fragments obtained after hybridization of a mouse RPF-1 probe to $50 \mu \mathrm{g}$ of yeast RNA or $50 \mu \mathrm{g}$ of total RNA from each of the indicated mouse tissues. The bottom shows control RNase protection reactions with $10 \mu \mathrm{g}$ of the same RNA samples using a $\beta$-actin probe. The top was exposed for $5 \mathrm{~d}$, the bottom for $8 \mathrm{hr}$.

\section{RPF-1 in subsets of amacrine and ganglion cells}

To identify more precisely the retinal cells expressing RPF-1, immunostaining experiments were carried out in the cat and monkey, species in which morphometric, anatomic, and physiological studies have defined many of the retinal cell types. In the cat retina, ganglion cells have been divided into three groups, $\alpha, \beta$, and $\gamma$, which have large, medium, and small soma sizes, respectively (Boycott and Wassle, 1974), and these correspond to the physiologically defined Y, X, and W groups (Cleland et al., 1975; Saito, 1983; Fukuda et al., 1985). Amacrine cells in the cat retina, as in other mammalian retinas, constitute an extremely heterogeneous group of cells, with cell bodies in both the inner part of the inner nuclear layer and in the ganglion cell layer. To facilitate a quantitative analysis of RPF-1-expressing cells, flatmounts of cat retinae were triple-stained with anti-RPF-1 [visualized with horseradish peroxidase (HRP)], AB5, a monoclonal antibody previously shown to stain ganglion cells (Fry et al., 1985) (visualized with fluorescein), and 4'6-diamidino-2-phenylindole (DAPI) (Fig. 9 ). Within the ganglion cell layer, RPF-1 is present in $50-60 \%$ of the cells, and this staining was confined to nuclei, as in the mouse retina. If we assume that $\mathrm{AB} 5$ stains all ganglion cells in the cat retina, then approximately half of the RPF-1-stained cells are ganglion cells; the remainder are presumed to be displaced amacrine cells. Among ganglion cells, the RPF-1-staining intensity varied widely. A fraction of small- and medium-sized cells stained most strongly, whereas the large $(\alpha)$ cells stained weakly or not at all. Within the inner nuclear layer, RPF-1 staining was found only in the innnermost layer of cells, indicating that these are amacrine cells. We conclude from this analysis that in the cat retina, RPF-1 is expressed in many $\beta$ and $\gamma$ ganglion cells and in a subset of amacrine cells.

In the monkey retina (Rodieck, 1988), $\sim 80 \%$ of ganglion cells project to the parvocellular layers of the LGN, have small cell bodies, and carry color opponent signals (P-cells). An additional $10 \%$ of ganglion cells project to the magnocellular layers of the LGN, have large cell bodies, and carry luminance signals (Mcells). The remaining $10 \%$ of ganglion cells comprise a number of physiologically and morphologically distinct types that project to targets other than the LGN, principally the tectum (superior colliculus) and pretectum. In the primate retina, ganglion cell density decreases $\sim 100$-fold from center to periphery. Because the density of displaced amacrine cells decreases less steeply, the ratio of amacrine to ganglion cells increases with eccentricity, from $\sim 1: 20$ in the center to $\sim 1: 1$ in the periphery (Wassle et al., 1989).

In cross-sections of the macaque retina, the RPF-1 immunostaining pattern resembles that seen in mouse retinae, except that the amacrine cells in the inner nuclear layer are stained more strongly in the macaque (Fig. 10A,B). Immunostaining of flatmounts of macaque retina shows a small population of cells that stain intensely for RPF-1, and a large population that stains at either weak or intermediate levels. The numerical density of the most strongly stained cells varies little with eccentricity, whereas the density of the less strongly stained cells falls rapidly with eccentricity (Fig. $10 C-E$ ). To characterize further the identities of the RPF-1-expressing cells, we immunostained retinae that were retrogradely labeled from the LGN by iontophoretic injection of Texas red-conjugated or fluorescein-conjugated dextran. Injection into both the magno- and parvocellular layers of the LGN revealed many hundreds of backfilled ganglion cells, including both large and small types, all of which stained at either weak or intermediate intensity with anti-RPF-1 antibodies (Fig. 11). These data indicate that $\mathrm{P}$ - and M-type ganglion cells contain low to intermediate levels of RPF-1. The data do not rule out the possibility that other less abundant ganglion or amacrine cell types also contain these levels of RPF-1. The strongly immunostained cells could represent either displaced amacrine cells or an unusual population of ganglion cells.

\section{DISCUSSION}

\section{RPF-1, a complex POU-domain gene}

This paper describes the identification of a new POU-domain gene, RPF-1. The structure of the RPF-1 transcription unit is unusual in its length, at least $125 \mathrm{~kb}$, and in the complexity of differential splicing inferred from the structure of cDNA clones and RT-PCR products. Alternate exon structures are observed at four locations within the transcription unit. Any one of four exons is present at the $5^{\prime}$ end of the coding region, possibly representing the use of alternate promotors; exon 6 is variably present, producing an in-frame insertion or deletion of 47 amino acids outside the DNA binding domain; exons 8 and 9 are variably present, generating a prematurely truncated protein lacking the POU domain; and exon 10 is present in either of two forms that differ in the choice of splice acceptors, thereby creating a consensus POU domain or an alternate POU domain in which the DNA recognition helix of the POU-specific domain is interrupted by an 

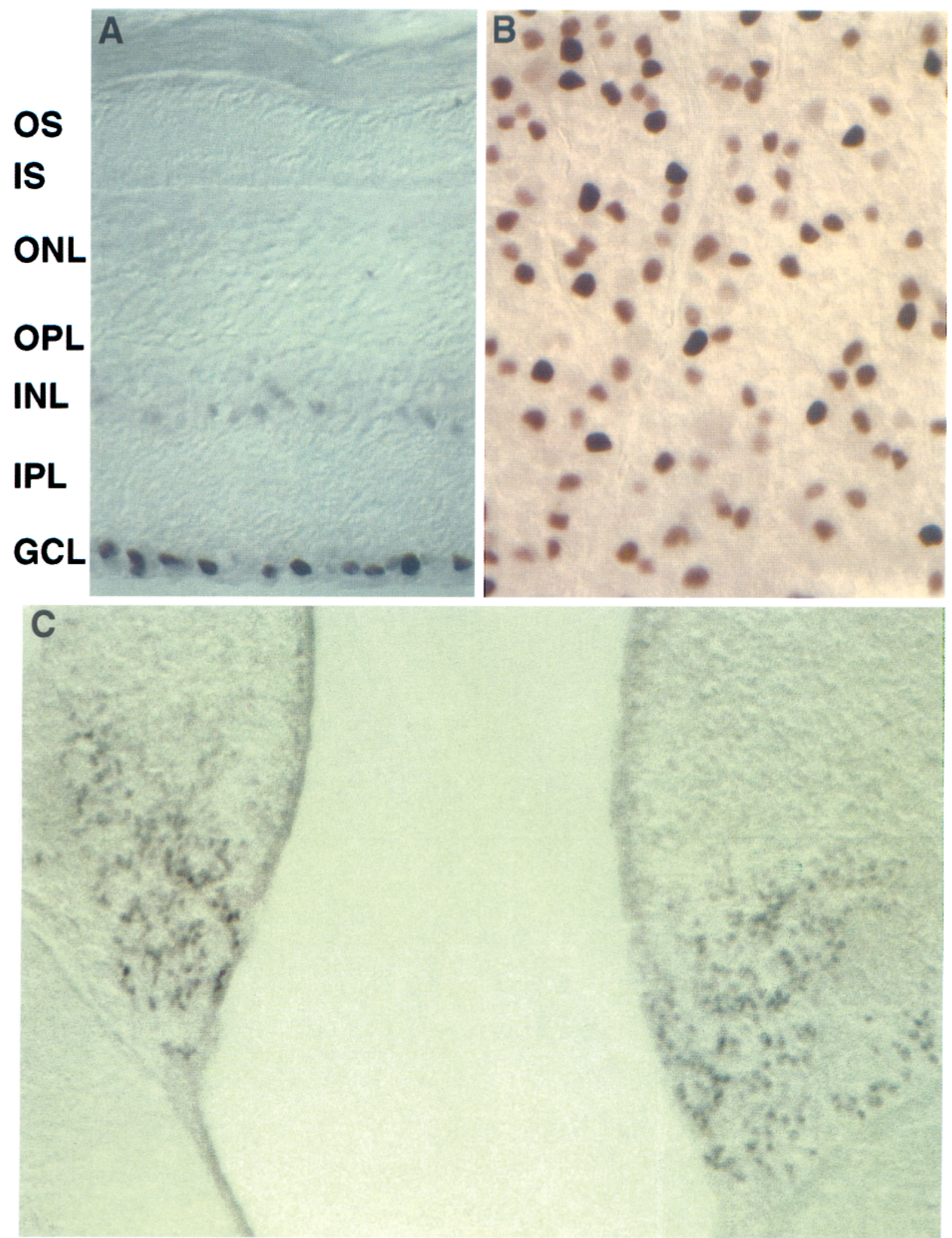

Figure 7. RPF-1 in the adult mouse. $A$, Cross-section of the adult mouse retina showing RPF-1 immunostaining in the ganglion and amacrinc cell layers. $B$, Flatmount of the adult mouse retina after RPF-1 immunostaining; the plane of focus is in the ganglion cell layer. $C$, RPF-1 immunostaining of the medial habenula in the adult mouse brain. The dorsal third ventricle is seen at the center. $O S$, Outer segment; $I S$, inner segment; $O N L$, outer nuclear layer; $O P L$, outer plexiform layer; $I N L$, inner nuclear layer; $I P L$, inner plexiform layer; $G C L$, ganglion cell layer. 

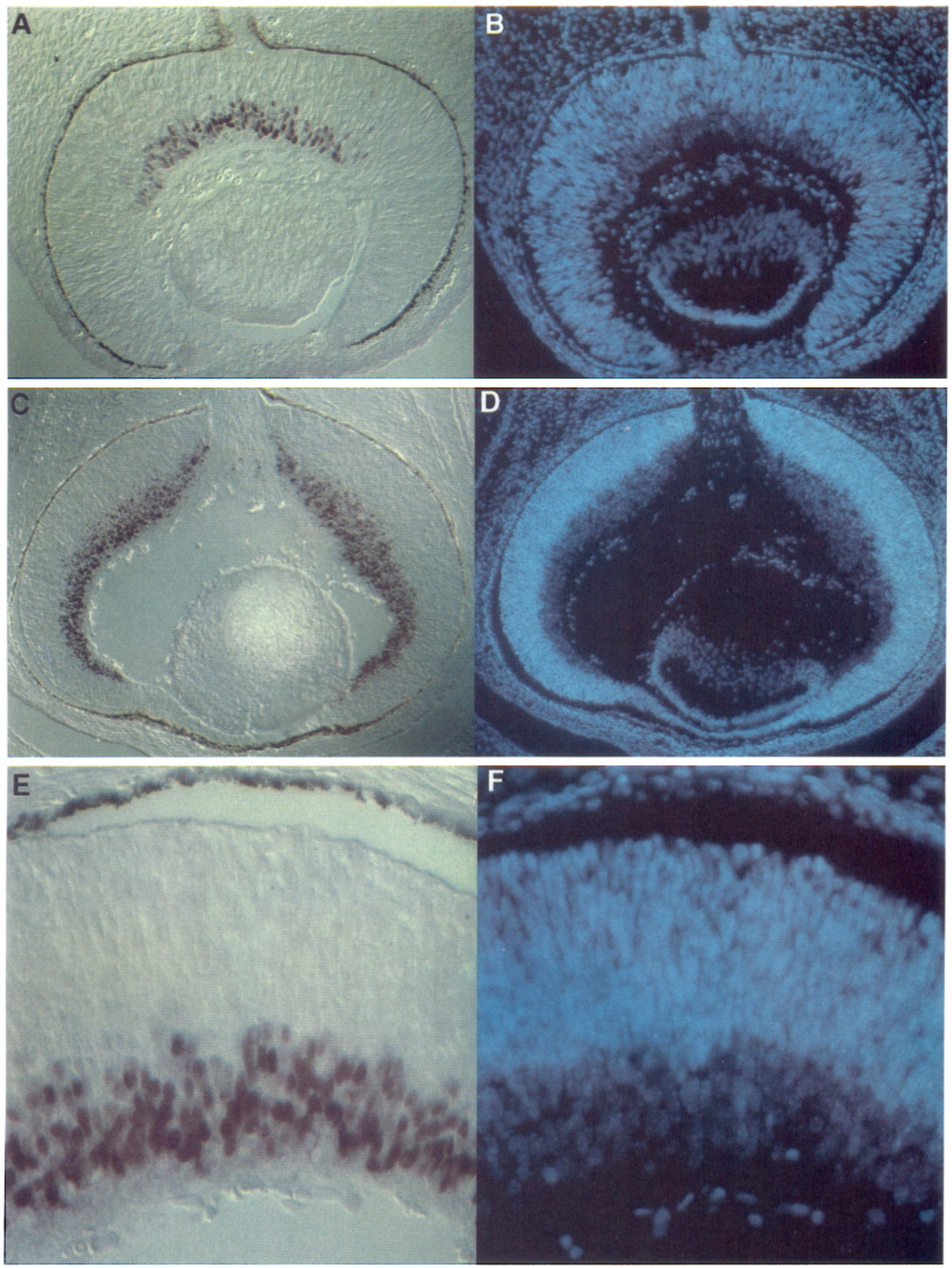

Figure 8. Distribution of RPF-1 in the developing mouse retina. Cross-section of the developing mouse eye showing RPF-1 immunoreactivity ( $A$, $C$, $E$ ) and DAPI staining to visualize nuclei $(B, D, F)$. Tissues were obtained at the following ages: e13 $(A, B)$, e16 $(C-F)$. The immunoperoxidase reaction product partially quenches the DAPI fluorescence. 

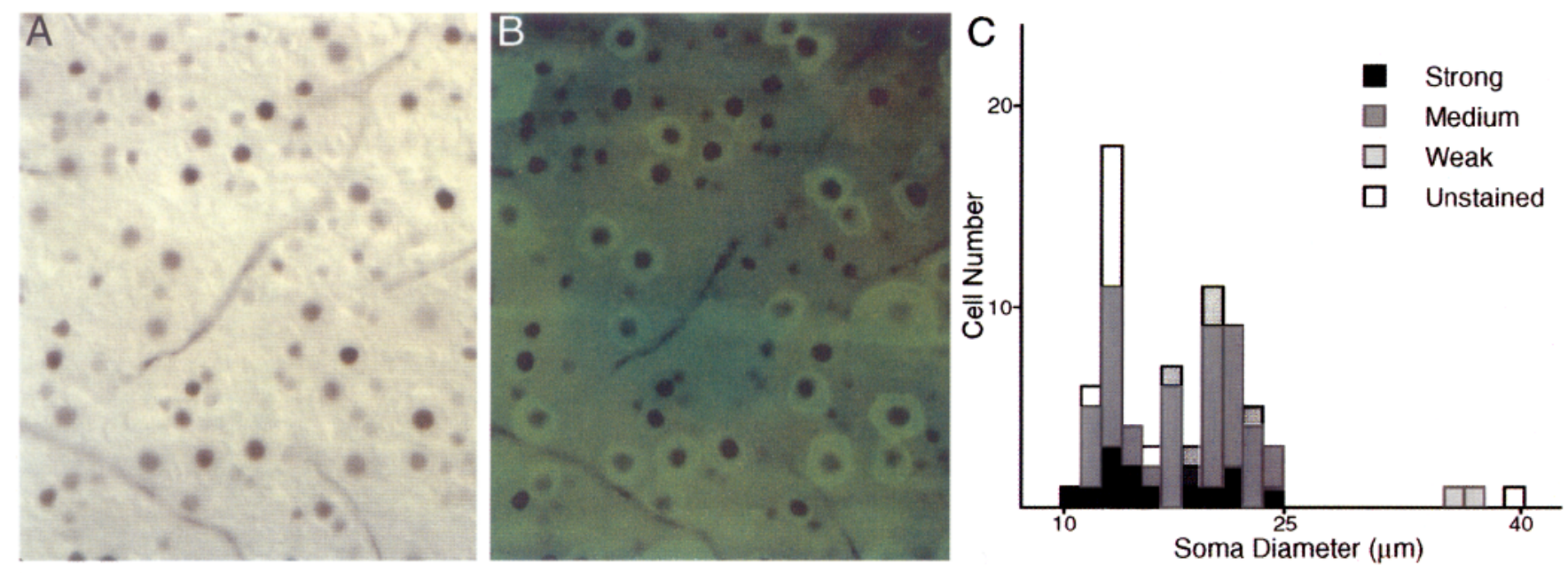

Figure 9. Distribution of RPF-1 in the cat retina. Wholemount double immunostaining of midperipheral cat retina using rabbit anti-RPF-1 antibodies visualized with the $\mathrm{ABC}$ peroxidase method $(A)$ and mouse $\mathrm{mAb} \mathrm{AB} 5$ visualized with a fluorescein-conjugated second antibody $(B)$. $C$, Histogram showing the RPF-1 staining intensity among different size classes of cells immunoreactive for mAb AB5. The region shown is from the midperipheral retina.

in-frame insertion of 36 amino acids (Figs. 3, 4). If each of the observed differential splicing events can occur independently, then the RPF-1 gene has the potential to generate 24 different proteins. The 24 isoforms can be divided into six major classes that differ internally by the presence or absence of alternate coding sequences.

Although the functional effects of differential splicing of exons 1 and 6 remain to be determined, generation of transcripts lacking a POU domain or encoding the alternate POU domain would be predicted to dramatically impair the DNA binding properties of the resulting protein. In vitro experiments with POU domains produced as GST fusion proteins confirm this prediction with respect to the alternate POU domain. In gel mobility shift assays, the consensus RPF-1 POU domain bound with moderate affinity to an Oct-1 site, whereas the alternate POU domain failed to bind. A similar difference in affinity was observed during in vitro selection of DNA binding sites. The simplest interpretation of these data are that the 36 amino acid insertion in the DNA recognition helix of the POU-specific domain sterically disrupts protein-DNA binding. We also observed in these experiments that the consensus RPF-1 POU domain bound to its selected DNA targets with lower affinity and specificity than did a control Oct-1 POU domain, suggesting that the RPF-1 POU domain may require additional protein-protein interactions to bind tightly to DNA.

If the insertion within the POU-specific domain functioned only to disrupt protein-DNA contacts, we would expect its sequence to drift over time, although this drift might be constrained by the nucleotide sequence requirements for differential splicing. Surprisingly, a comparison of human and mouse RPF-1 sequences shows that this region has remained identical for 200 million years, at both the nucleotide and amino acid levels. This identity indicates an important functional role for the alternate POU domain and suggests the possibility that the inserted polypeptide adopts a definite three-dimensional structure. It is tempting to speculate further that RPF-1 isoforms that carry the alternate POU domain may interact with other cellular proteins and that these protein-protein interactions involve the 36 amino acid insertion.

\section{Implications for retinal diversity and development}

Analysis of the time and tissue distribution of RPF-1 transcripts and protein reveals a remarkably specific pattern. Among major organs in the adult mouse, only the CNS contains RPF-1 transcripts, and within the CNS, RPF-1 expression is confined to the medial habenulla, to a dispersed population of neurons in the dorsal hypothalamus, and to subsets of amacrine and ganglion cells in the retina. Within the retinas of mice, cats, and monkeys, a consistent pattern of RPF-1 immunostaining is seen. In each species it is found in nuclei at the inner edge of the inner nuclear layer; these are presumed to be the nuclei of amacrine cells. Within the ganglion cell layer, RPF-1 seems to be expressed in most ganglion cells and in displaced amacrine cells, as determined by backfilling of ganglion cells from the LGN in the monkey and by immunostaining with a ganglion cell-specific antibody (AB5) in the cat. As noted previously for ganglion cell staining by antibodies to the Brn-3 family of POU-domain factors, the intensity of RPF-1 immunostaining varies among cells in a manner that is characteristic for each species (Xiang et al., 1993, 1995).

In the macaque retina, most of the P- and M-type ganglion cells have a low to intermediate level of RPF-1. The subset of cells within the ganglion cell layer that stain most intensely for RPF-1 are neither P- nor M-type ganglion cells, because they are not backfilled from the LGN and show little change in density with increasing eccentricity. They may represent either a group of displaced amacrine cells or an unusual population of ganglion cells. In the cat retina, almost all of the $\beta$ and $\gamma$ ganglion cells express RPF-1, and these RPF-1-expressing cells account for $\sim 90 \%$ of the ganglion cells. The $\alpha$ cells, which account for $\sim 5 \%$ of ganglion cells, stain weakly or not at all for RPF-1.

In the developing mouse CNS, RPF-1 immunostaining is most prominent within the retina where it first appears at day e11 within the developing ganglion cell layer. In the mouse, $\left[{ }^{3} \mathrm{H}\right]$ thymidine-labeling studies have shown that most ganglion cell precursors become postmitotic between e11 and e18, and amacrine cell precursors become postmitotic between e13 and e18 (Sidman, 1961). These newly postmitotic cells migrate inward from the dividing neuroblast layer to reach their final destinations within the developing retina, a pattern analogous to that observed 

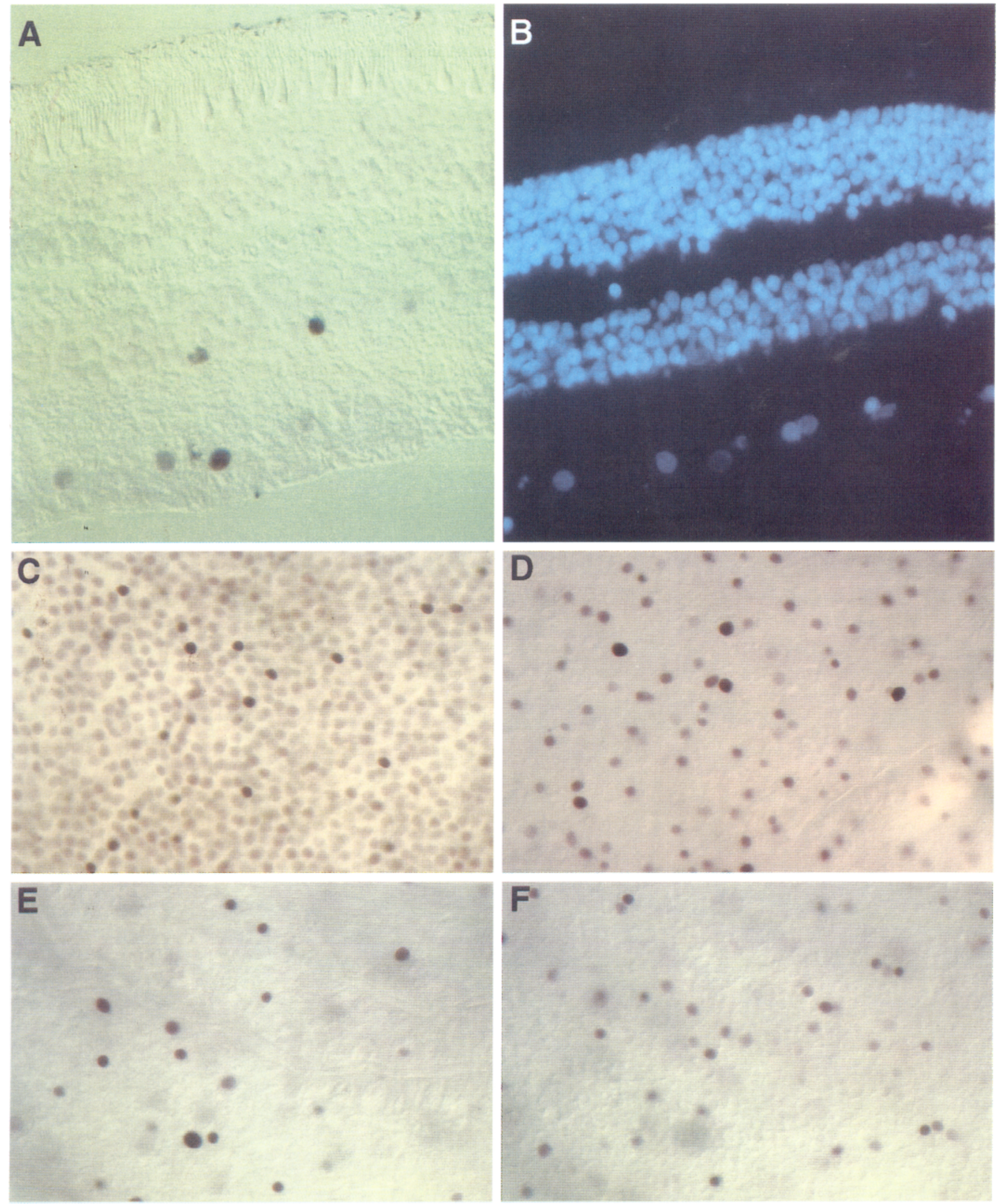

Figure 10. Distribution of RPF-1 in the macaque retina. Cross-section of adult macaque retina stained with anti-RPF-1 $(A)$ and DAPI $(B)$. Flatmounts of central $(C)$, midperipheral $(D)$, and far peripheral $(E, F)$ macaque retina stained with anti-RPF-1. $C, D$, and $E$ are visualized with the plane of focus in the ganglion cell layer; $F$ is visualized with the plane of focus in the inner part of the inner nuclear layer. 

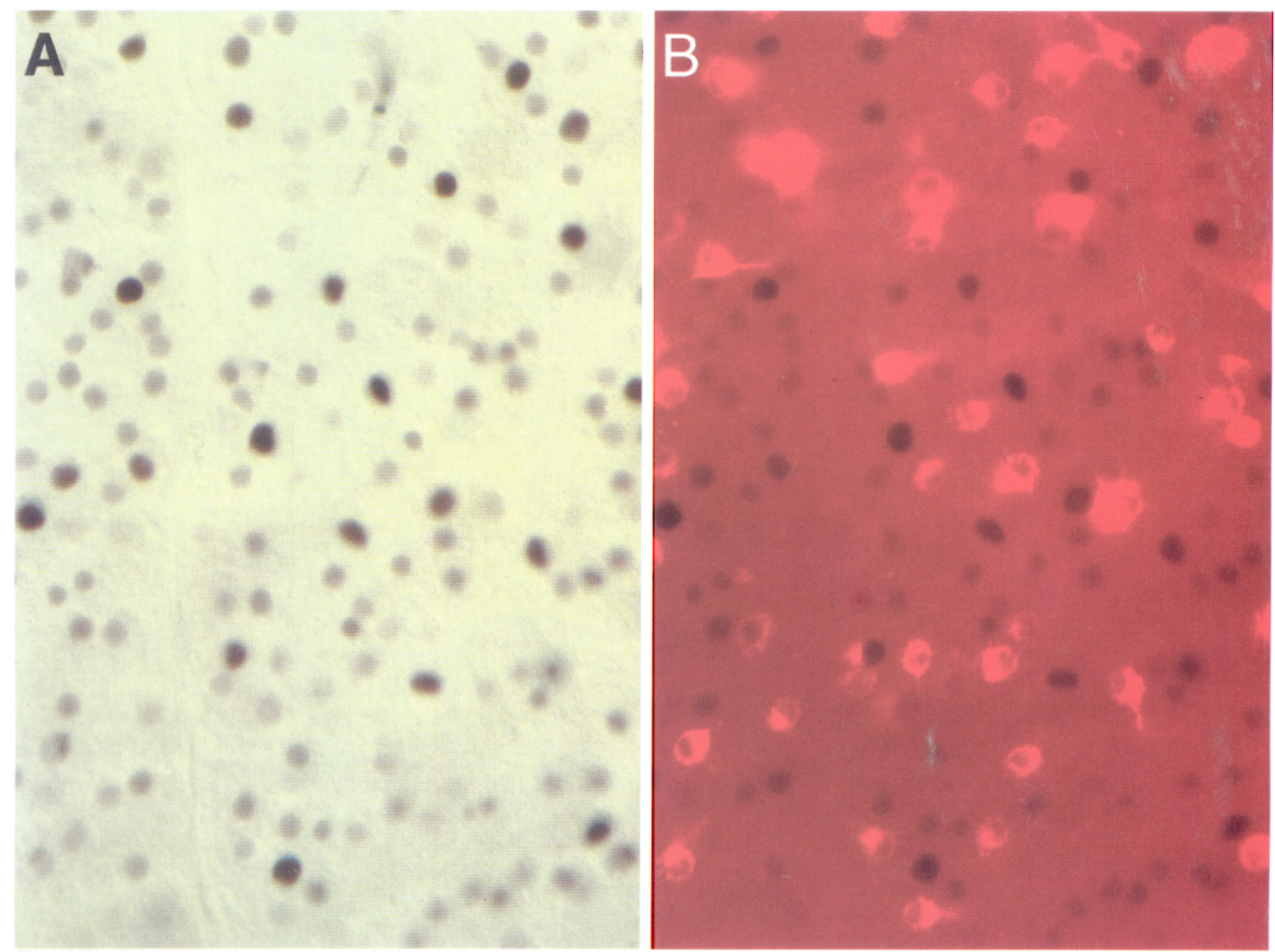

Figure 11. RPF-1 in backfilled macaque retinal ganglion cells. A macaque retina was immunostained with anti-RPF-1 after retrograde transport of Texas red-conjugated dextran from an injection that included both the parvocellular and magnocellular layers of the LGN. $A$, Anti-RPF-1 immunoreactivity visualized with HRP. $B$, Texas red fluorescence.

for the generation of cerebral cortical neurons from the ventricular zone. In the developing chicken retina, immunostaining with a ganglion cell-specific monoclonal antibody demonstrates that ganglion cells begin to differentiate shortly after their terminal mitosis and while they are still migrating (McLoon and Barnes, 1989; Wald and McLoon, 1995). The appearance of RPF-1 at the earliest stages of retinal differentiation and its presence in recently postmitotic cells suggest that RPF-1 is involved in early steps of ganglion and amacrine cell commitment. This inference is supported by experiments with Brn-3b, a POU-domain factor that in the adult retina is expressed only in ganglion cells. In the developing retina, the timing of Brn-3b expression resembles that of RPF-1, and recent experiments show that mice that are homozygous for a targeted disruption of the Brn-3b gene have $70 \%$ fewer ganglion cells (L. Gan, M. Xiang, L. Zhou, D. S. Wagner, W. H. Klein, and J. Nathans, unpublished observations). Targeted disruption of the RPF-1 gene should similarly clarify the role of this gene in ganglion and amacrine cell development.

\section{REFERENCES}

Anderson B, Schonemann MD, Pearse RV, Jenne K, Sugarman J, Rosenfeld MG (1993) Brn-5 is a divergent POU domain factor highly expressed in layer IV of the neocortex. J Biol Chem 268:23390-23398.
Bodner M, Castrillo J-L, Theill LE, Deerinck T, Ellisman M, Karin M (1988) The pituitary-specific transcription factor $G H F-1$ is a homeobox-containing protein. Cell 55:505-518.

Boycott BB, Wassle H (1974) The morphological types of ganglion cells of the domestic cat's retina. J Physiol (Lond) 240:397-419.

Chalfie M, Horvitz HR, Sulston JE (1981) Mutations that lead to reiterations in the cell lineages of $C$. elegans. Cell 24:59-69.

Cleland BG, Levick WR, Wassle H (1975) Physiological identification of a morphological class of cat retinal ganglion cells. J Physiol (Lond) 248:151-171.

Clerc RG, Corcoran LM, Lebowitz JH, Baltimore D, Sharp PA (1988) The B-cell-specific Oct-2 protein contains POU box- and homeo boxtype domains. Genes Dev 2:1570-1581.

Corcoran LM, Karvelas M, Nossal GJV, Ye Z-S, Jacks T, Baltimore D (1993) Oct-2, although not required for early B-cell development, is critical for later maturation and for postnatal survival. Genes Dev 7:570-582.

Deitcher DL, Fekete DM, Cepko CL (1994) Asymmetric expression of a novel homeobox gene in vertebrate sensory organs. J Neurosci 14:486-498.

Dowling JE (1987) The retina: an approachable part of the brain. Cambridge, MA: Harvard University.

Finney M, Ruvkin G, Horvitz HR (1988) The C. elegans cell lineage and differentiation gene unc- 86 encodes a protein with a homeodomain and extended similarity to transcription factors. Cell 56:757-769.

Frischauf A-M, Lehrach H, Poustka A, Murray N (1983) Lambda replacement vectors carrying polylinker sequences. J Mol Biol 170:827-842. 
Frohma MA, Dush MK, Martin G (1988) Rapid production of fulllength cDNAs from rare transcripts: amplification using a single gene-specific oligonucleotide primer. Proc Natl Acad Sci USA 85:8998 9002.

Fry KR, Tavella D, Su YYT, Peng YW, Watt CB, Lam DMK (1985) A monoclonal antibody specific for retinal ganglion cells. Brain Res 338:360-365.

Fukuda Y, Hsiao CF, Watanabe M (1985) Morphological correlates of Y, $X$, and $W$ type ganglion cells in the cat's retina. Vision Res 25:319-327.

Gerrero MR, McEvilly R, Turner E, Lin CR, O'Connell S, Jenne KJ, Hobbs MV, Rosenfeld MG (1993) Brn-3.0: a POU-domain protein expressed in the sensory, immune, and endocrine systems that functions on elements distinct from known octamer motifs. Proc Natl Acad Sci USA 90:10841-10845.

He X, Treacy MN, Simmons DM, Ingraham HA, Swanson LW, Rosenfeld MG (1989) Expression of a large family of POU-domain regulatory genes in mammalian brain development. Nature 340:35-42.

Herr W, Sturm R $\Lambda$, Clerc RG, Corcoran LM, Baltimore D, Sharp P $\Lambda$, Ingraham HA, Rosenfeld MG, Finney M, Ruvkin G, Horvitz HR (1988) The POU domain: a large conserved region in the mammalian Pit-1, Oct-1, Oct-2 and Caenorhabditis elegans unc-86 gene products. Genes Dev 2:1513-1516.

Ingraham HA, Chen R, Mangalam HJ, Elsholtz HP, Flynn SE, Lin CR, Simmons DM, Swanson L, Rosenfeld MG (1988) A tissue-specitic transcription factor containing a homeodomain specifies a pituitary phenotype. Cell 55:519-529.

Johansen T, Moens U, Holm T, Fjose A, Krauss S (1993) Zebrafish pou(c): a divergent POU family gene ubiquitously expressed during embryngenesis. Nucleic Acids Res 21:475-483.

Klemm JD, Rould MA, Aurora R, Herr W, Pabo C (1994) Crystal structure of the Oct-1 POU domain bound to an octamer site: DNA recognition with tethered DN $\Lambda$-binding modules. Cell 77:21 32.

Li S, Crenshaw EB, Rawson EJ, Simmons DM, Swanson LW, Rosenfeld MG (1991) Dwarf locus mutants lacking three pituitary cell types result from mutations in the POU-domain gerle Pii-1. Nature 347:528 -533.

Liu ISC, Chen J, Ploder L, Vidgen D, van der Kooy D, Kalnins VI, McInnes RR (1994) Developmental expression of a novel murine homeobox gene (Chxl0): evidence for roles in determination of the neuroretina and inner nuclear layer. Neuron 13:377-393.

McLoon SC, Barnes RB (1989) Early differentiation of retinal ganglion cells: an axonal protein expressed by premigratory and migrating retinal ganglion cells. J Ncurosci 9:1424-1432.

Nathans I Thomas D, Hogness DS (1986) Molecular genetics of human color vision: the genes encoding blue, green, and red pigments. Science 232:193-202.

Okamoto K, Wakamiya M, Noji S, Koyama E, Taniguchi S, Takemura R, Copeland NG, Gilbert DJ, Jenkins N, Muramatsu M, Hamada $H$ (1993) A novel class of murine POU gene predominantly expressed in central nervous system. J Biol Chem 268:7449-7457.

Paxinos G, Watson C (1986) The rat brain in stereotaxic coordinates. San Diego: Academic.

Rodieck RW (1973) The vertebrate retina: principles of structure and function. New York: Freeman.

Rodieck RW (1988) The primate retina. Comp Primate Biol 4:203-278.
Rodieck RW, Brening RK (1983) Retinal ganglion cells: properties, types, genera, pathways, and trans-species comparisons. Brain Behav Evol 23:121-164

Rosenfeld MG (1991) POU-domain transcription factors: pou er ful developmental regulators. Genes Dev 5:897-907.

Saito H-A (1983) Morphology of physiologically identified X-, Y-, and W-lype retinal ganglion cells of the cal. J Comp Neurol 221:279-288.

Sambrook J, Fritsch EF, Maniatis T (1989) Molecular cloning: a laboratory manual, 2nd ed. New York: Cold Spring Harbor.

Schambra UB, Lauder J, Silver J (1992) Atlas of the prenatal mouse brain. San Diego, CA: Academic.

Scheidereit C, Cromlish JA, Gerster T, Kawakima K, Balmaceda C-G, Currie A, Roeder RG (1988) A human lymphoid-specific transcription factor that activates immunoglobulin genes is a homeobox protein. Nature 336:551-557.

Sidman RL (1961) Histogenesis of mouse retina studied with ${ }^{3} \mathrm{H}$ thymidine. In: The structure of the eye (Smelser G, ed), pp 487-505. New York: $\Lambda$ cademic.

Sidman RL, Angevine JB, Pierce TP (1971) Atlas of the mouse brain and spinal cord. Cambridge: Harvard UP.

Stone J (1983) Parallel processing in the visual system: the classification of retinal ganglion cells and its impact on the neurobiology of vision. New York: Plenum.

Studier FW, Rosenberg AH, Dunn JJ, Dubendorff JW (1990) Use of T7 RNA polymerase to direct expression of cloned genes. Methods Enzymol 185:60-89.

Swaroop A, Xu JZ, Pawar H, Jackson A, Skolnick C, Agarwal N (1992) A conserved retina-specific gene encodes a basic motif/leucine zipper domain. Proc Natl Acad Sci USA 89:266-270.

Thicsen H-J, Bach C (1990) Target detection assay: a versatile procedure to determine DNA binding sites as demonstrated on Sp1 protein. Nucleic Acids Res 18:3203-3209.

Thor S, Ericson J, Brannstrom T, Edlund T (1991) The homeodomain LIM protein Isl-1 is expressed in subsets of neurons and endocrine cells in the adult rat. Neuron 7:881-889.

Turner EE, Jenne KJ, Rosenfeld MG (1994) Brn-3.2: a Brn-3-related transcription factor with distinctive central nervous system expression and regulation by retinoic acid. Neuron 12:205-218.

Wald DK, McLoon SC (1995) Immediate differentiation of ganglion cells following mitosis in the developing retina. Neuron 14:117-124.

Walther C, Gruss P (1991) Pax-6, a murine paired box gene, is expressed in the developing CNS. Development 113:1435-1449.

Wassle H, Boycott BB (1991) Functional architecture of the mammalian retina. Physiol Rey 71:447-479.

Wassle H, Grunert U, Rohrenbeck J, Boycott BB (1989) Cortical magnification factor and the ganglion cell density in the primate retina. Nature 341:643-646.

Xiang M, Zhou L, Macke JP, Yoshioka T, Hendry SHC, Eddy RL, Shows TB, Nathans J (1995) The Brn-3 family of POU-domain factors: primary structure, binding specificity, and expression in subsets of retinal ganglion cells and somatosensory neurons. J Neurosci 15:4762-4785.

Xiang M, Zhou L, Peng Y-W, Eddy RL, Shows TB, Nathans J (1993) Brn-3b: a POU-domain protein expressed in a subset of retinal ganglion cells. Neuron 11:689-701. 